\title{
Hindlimb lateral and medial acropodial series of cattle are uneven in form
}

\author{
Séries acropodias laterais e mediais são irregulares na forma
}

\author{
Pere M. Parés-Casanova*, Kirian Narcís Jones Capdevila, Laura Castel Mas \\ Department of Animal Science, ETSEA, University of Lleida, Lleida, Catalunha, Espanha. * Author for correspondence: \\ peremiquelp@ca.udl.cat
}

Submission: 28/05/2020/ Acceptance: 02/09/2020

\begin{abstract}
In bovines, fore and hind lateral claws are larger than the medial claws and the heel are deeper and the sole thicker. On this anatomical basis, we hypothesized that it must imply a form (size+shape) asymmetry of the digits. To test this hypothesis, we studied the acropodiums (digital series) of 15 young bovines belonging to Brown Pyrenean breed, irrespective of the gender. Dorso-plantar radiographies were obtained for each hindlimb and the form was studied in a sample of 30 hindlimbs (15 right and 15 left). Images were studied by geometric morphometric methods. A set of 7 paired landmarks on medial and lateral digital series and one axial landmark was used for the study. Lateral and medial digits were uneven both in size and shape, expressing both fluctuating and directional asymmetries. Directional asymmetries would suggest a different function in weight bearing. We hypothesize lateral digits serve to stabilize the centre of gravity to a greater extent than medial digits. These findings prompt careful reassessment of the function of each of the digital series during standing and during locomotion in future researches.
\end{abstract}

KEYWORDS: digital bones, fluctuating asymmetry, locomotion, Pyrenean Brown cattle.

\section{RESUMO}

Em bovinos, cascos laterais anteriores e posteriores são maiores que os cascos mediais, o talão é mais profundo e o sola mais grosso. Nesta base anatômica, supomos que deve implicar em uma assimetria de forma (tamanho+forma pura) dos dígitos. Para testar essa hipótese, estudamos os acropodiums (série digital) de 15 bovinos jovens pertencentes à raça Pyrenean Brown, independentemente do sexo. Radiografias dorso-plantar foram obtidas para cada membro posterior e a forma foi estudada em uma amostra de 30 membros (15 à direita e 15 à esquerda). As imagens foram estudadas por métodos geométricos morfométricos. Um conjunto de 7 pontos de referência emparelhados em séries digitais medial e lateral e um marco axial foram usados para o estudo. Os dígitos laterais e medial eram irregulares tanto em tamanho quanto em forma, expressando assimetrias flutuantes e direcionais. Assimimetrias direcionais sugerem uma função diferente para suportar peso. Nós hipotetizamos que os dígitos laterais servem para estabilizar o centro de gravidade em maior medida do que os dígitos mediais. Esses achados sugerem uma reavaliação cuidadosa da função de cada uma das séries digitais durante a posição e durante a locomoção em pesquisas futuras.

PALAVRAS-CHAVE: ossos digitais, assimetria flutuante, locomoção, vaca Pyrenean Brown.

\section{INTRODUCTION}

In bilaterally symmetric structures, size and shape can differ between sides (MANCINI et al. 2005, AUERBACH \& RUFF 2006, SFORZA et al. 1998). Asymmetries can be expressed as fluctuating asymmetry (FA) and as directional asymmetry (DA) (GRAHAM et al. 1993, AUFFRAY et al. 1999, COSTA et al. 2015). FA is generally the result of genetic or environmental stress (ALADOS et al. 2001, ANGELOPOULOU et al. 2009, BLACKBURN 2011) and is considered a negative indicator of the ability to resist random and small developmental accidents (GRAHAM et al. 1993). DA occurs when there is a consistent difference between sides (BERNS 2013, GINOT et al. 2018) and it has generally a genetic basis (CARTER et al. 2009), so usually is not considered to be due to environmental or developmental stress (GINOT et al. 2018).

Cattle have four digital series (the acropodia), III and IV being functional whereas II and V series are vestigial (BARONE 1999). Metapodium is composed of the two fused third and fourth metacarpal/metatarsal 
bones (BARONE 1999). This composite bone, colloquially known as "cannon bone", provides two separate epiphyses for the third and fourth digital series, which are each composed of the three digits. There are many detailed studies on the hoof size, suspensory apparatus and vascular anatomy of the bovine limb, but there is lack of knowledge about detailed morphometry of the digital bones in cattle (CERVENY 1985, OCAL et al. 2004). In bovines, the outside claw of the hind legs bears the burden of the weight load during locomotion and this may be the reason why the lateral claw is larger than the medial claw and the heel is deeper and the sole thicker (BETEG et al. 2007, WILSON et al. 2009, MUGGLIA et al. 2011). We hypothesized that this clay asymmetry must imply a form (size+shape) asymmetry of the digits.

Geometric morphometrics (GM) is based on the Cartesian coordinates of landmarks (measurement points) that are homologous across all measured individuals (MITTEROECKER \& GUNZ 2009). In contrast to traditional linear methods, GM preserves the geometry of the measured landmark configurations, and statistical results can thus be represented as shape deformations (MITTEROECKER \& GUNZ 2009). GM is of superior statistical power than most traditional morphometric approaches and is particularly effective for anatomical exploratory studies. Moreover, morphometric methods are very useful in standardizing and separating the different sources of asymmetry.

The aim of this study was to determine object asymmetries in middle and distal hindlimb digits on postmortem specimens, from Pyrenean Brown animals based on radiographs and assessed by GM. Hindlimbs are related to the biomechanics of locomotion (EBLING et al. 2019), so we have limited our study on them with no consideration to forelimbs. Notably, to the best of our knowledge, a radiographic method had not been used before for osteometric studies in bovines of the Pyrenean Brown breed. As the sample was from animals not subjected to feet care, we expect to describe "natural" asymmetries. The study is of interest because of its implications on health and management of meat cattle maintained under extensive conditions (grazing all year round and outdoor management), and thus selected not only for meat production, but also for functional traits (rusticity). It is part of a work to gain knowledge on the functional conformation of that typically bovine Catalonian breed.

\section{MATERIAL AND METHODS}

Cadaveric samples of 30 hindlimb autopodes from Pyrenean Brown calves (range: 205-407 days of age, body carcass $453.3 \pm 73.5 \mathrm{~kg}$ ) collected in a commercial slaughterhouse were collected (15 right hindlimbs and 15 left hindlimbs). Study was done on randomly selected animals. All animals were clinically sound and without lameness, according to ante mortem abattoir official veterinary inspection and none of them had previously undergone claw trimming. Sex and individual carcass weight were not considered for this study. Post-mortem use of bones from commercial abattoirs does not require an approval from an Ethics Committee.

Images were obtained using a computed radiography system. The exposure factors for dorso-plantar view were $60 \mathrm{kV}$ and $3.2 \mathrm{~m}$. As with the foot to be examined placed on a block ca. $5 \mathrm{~cm}$ high and the $\mathrm{x}$-ray beam centered approximately to the fetlock. The cassette was vertically positioned as close as possible to the limb, without touching it. A total of seven landmarks occurring on both sides of the acropodium and one axial on distal metatarsus were used (Figure 1). These landmarks were chosen as they had a good representation of the overall acropodial shape and to detect important features of asymmetry. The captured images were transformed to TpsUtil v. 1.40 software (ROHLF 2015a) and landmarks recorded using TpsDig v. 2.26 software (ROHLF 2010).

To obtain the shape data, landmark configurations were superimposed using the generalized Procrustes method, based on a generalized least-squares minimization of the distance between corresponding landmarks (BOOKSTEIN 1991). Landmark configurations were compared by this superimposition, which is achieved by translating, rotating and scaling all configurations to a common reference system (the mean) (KLINGENBERG 2015). As a proxy for size we used the centroid size (CS), which corresponds to the squared root of the sum of the squared distances from each landmark to the centroid (BOOKSTEIN 1991, KUBICKA et al. 2018). 


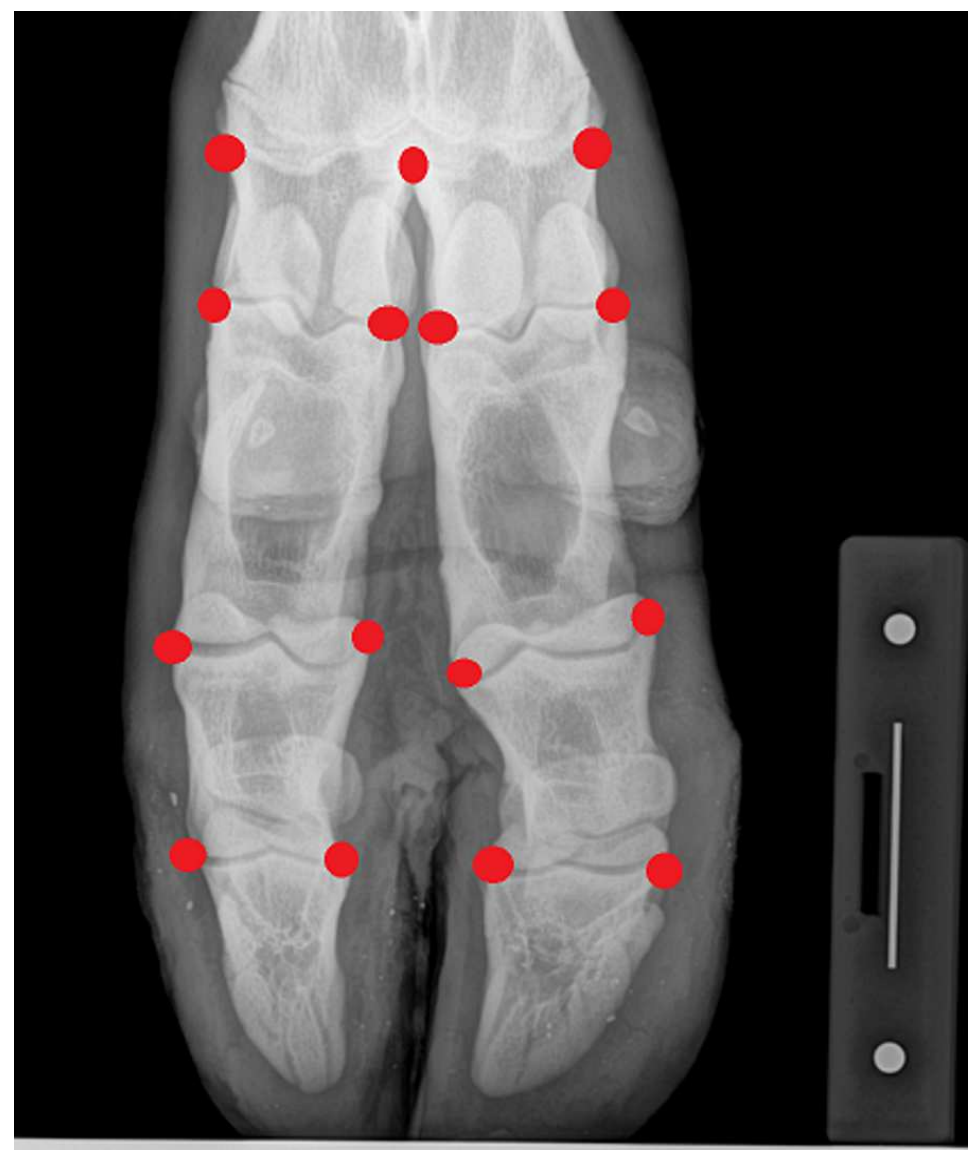

Figure 1. Dorso-plantar view of acropode (in natural standing position) on which 7 landmarks occurring on both sides of the acropodium and one axial on distal metatarsus were located.

\section{Statistical analyses}

We used TpsSmall v. 1.33 software (ROHLF 2015b) to test whether the observed variation in shape was sufficiently small that the distribution of points in the tangent space could be used as a good approximation of their distribution in shape space (BOOKSTEIN 1991). Superimposed landmarks were assessed for asymmetry of shape in relation to individuals (symmetric component of variation), asymmetric component of variation (DA and FA), and measurement error. FA was interpreted as the effect interaction "individual * side", while DA as the effect "side". Then we analysed data with the nonparametric paired Wilcoxon $W$ test for medial and lateral series. A regression of CS versus shape has done, with values for CS logarithmically transformed.

Analyses were done with MorphoJ v. 1.06a (KLINGENBERG 2011) and PAST v. 2.17c (HAMMER et al. 2001) softwares. Levels of statistical significance were computed using 10,000 random permutations.

\section{RESULTS}

To assess whether the variation between the two spaces (Euclidean and tangent) was minimal, correlations between the tangent distances and the Procrustes distances were also computed using the tpsSmall v. 1.33 software (ROHLF 2015b). The result of this correlation (0.9995) confirmed that both spaces were almost identical.

\section{Size asymmetries}

There were size differences between lateral and medial acropodial series for right and left hindlimb $(p<0.01)$. Paired Wilcoxon test reflected than medial and lateral digital series presented size differences, medial series appearing for both statistically smaller than lateral series ( $W=102, p=0.015$ for right hindlimbs; $W=104, p=0.035$ for left hindlimbs).

\section{Shape asymmetries}

There appeared directional asymmetries (highly significative "side" effect, e.g. DA, $p<0.01$ ) as well fluctuating asymmetries (highly significative "side $x$ individual" interaction effect, e.g. FA, $p<0.01$ ), for both right and left hindlimbs (Table 1). MANOVA corroborated these asymmetries (Table 1). For hindlimbs, displacement was centered on articulation between medial and distal digits. No significative correlation of shape against size appeared $(p=0.710)$. 
Table 1. Procrustes ANOVA for size and shape of hindlimbs of Pyrenean Brown calves $(n=30)$, with a significant effect of "side" (directional asymmetry) and "side*individual" interaction effect (fluctuating asymmetry) for each group. Sums of squares (SS) and mean squares (MS) are in units of Procrustes distances (dimensionless).

\begin{tabular}{|c|c|c|c|c|c|}
\hline \multicolumn{6}{|c|}{$\begin{array}{l}\text { 1/ Right hindlimbs }(n=15) \\
\text { Centroid size }\end{array}$} \\
\hline Effect & SS & MS & df & $\mathrm{F}$ & $\mathrm{P}$ \\
\hline Individual & 215996.166354 & 15428.297597 & 14 & 114.41 & $<.0001$ \\
\hline Error & 1887.832724 & 134.845195 & 14 & & \\
\hline \multicolumn{6}{|l|}{ Shape } \\
\hline Effect & SS & MS & $\mathrm{df}$ & $\mathrm{F}$ & $\mathrm{P}$ \\
\hline Individual & 0.02222497 & 0.0001221152 & 182 & 2.61 & $<.0001$ \\
\hline Side & 0.00655716 & 0.0005043970 & 13 & 10.76 & $<.0001$ \\
\hline Individual $^{*}$ side & 0.00853121 & 0.0000468748 & 182 & 2.79 & $<.0001$ \\
\hline Error & 0.00611395 & 0.0000167966 & 364 & & \\
\hline \multicolumn{6}{|c|}{ MANOVA test of effects } \\
\hline Effect & Pillai trace & $P$ & & & \\
\hline Side & 1.00 & 0.0051 & & & \\
\hline Individual $^{*}$ side & 7.57 & 0.0130 & & & \\
\hline \multicolumn{6}{|c|}{ 2/ Left hindlimbs $(n=15)$} \\
\hline \multicolumn{6}{|l|}{ Centroid size } \\
\hline Effect & SS & MS & $d f$ & $\mathrm{~F}$ & $\mathrm{P}$ \\
\hline Individual & 268369.001216 & 19169.214373 & 14 & 216.14 & $<.0001$ \\
\hline Error & 1330.343260 & 88.689551 & 15 & & \\
\hline \multicolumn{6}{|l|}{ Shape } \\
\hline Effect & SS & MS & df & $\mathrm{F}$ & $\mathrm{P}$ \\
\hline Individual & 0.02236262 & 0.0001228715 & 182 & 2.65 & $<.0001$ \\
\hline Side & 0.00910804 & 0.0007006186 & 13 & 15.08 & $<.0001$ \\
\hline Individual* side & 0.00845421 & 0.0000464517 & 182 & 2.99 & $<.0001$ \\
\hline Error & 0.00606899 & 0.0000155615 & 390 & & \\
\hline \multicolumn{6}{|c|}{ MANOVA test of effects } \\
\hline Effect & Pillai trace & $p$ & & & \\
\hline Side & 1.00 & 0.0082 & & & \\
\hline Individual* side & 7.61 & 0.0024 & & & \\
\hline
\end{tabular}

\section{DISCUSSION}

In the very first stages of the vertebrates' development, a midline divides embryos into two symmetric parts, and this phenomenon constitutes the base for lateralization (SFORZA et al. 1998). Then, although there can be an apparent macroscopic symmetric pattern, analysis in proof can reveal morphologic asymmetries. In bovines, the outside claw of the hind legs bears the burden of the continuously changing weight load during locomotion. The medial series of artiodactyls' acropodes is somewhat more strongly developed than the lateral portion (BARTOSIEWICZ et al. 1993). But many bones, including the digital bones studied, are complex structures and difficult to be assessed with objective measurement. Geometric morphometric techniques of these bones may be a potential method of obtaining information on its size and shape and, by consequence, structure. This is why we studied the hypothesized asymmetry between acropodial series using geometric morphometric techniques, resulting that in hindlimbs, the lateral series of acropodes is more strongly developed than the medial portion. In other words, according to our data, the larger size would be on IV (lateral) series than on III (medial) series.

There are several reasons to think that a difference in digit size could be adaptive for cattle. We could explain this fact according to the main vertical axis supporting the body weight: in hindlimbs, the lateral digitals would fall in it, so being more strongly developed, e.g. larger, than the medial. This biological significance has been described in other studies (MAIERL et al. 2002), e.g. that the body weight and the additional dynamic loading is predominantly taken over by the abaxial part of the claw, while the axial aspects are less loaded. Enthesis for digital flexor and extensor muscles would explain the differences in shape. 
In summary, our results showed significant differences in the form of the paired digits of domestic cattle, although we must be cautious as results are from isolated limbs and not whole animals so nothing can be inferred of functional correlation (for instance body weight) to this asymmetry. Now, it could be interesting to perform new researches in order to study if there are sexual dimorphism in acropodial asymmetry and an increase with age.

\section{CONCLUSION}

In cattle, it seems that lateral and medial digits were uneven both in size and shape, expressing both fluctuating and directional asymmetries. Directional asymmetries would suggest a different function in weight bearing taken over by each series.

\section{ACKNOWLEDGEMENTS}

The authors acknowledge all the facilitations offered by abattoir MAFRISEU SL and its official Veterinary Miquel Àngel Alberton. We also thank the editor for his insightful comments.

\section{REFERENCES}

ALADOS CL et al. 2001. Translational and fluctuating asymmetry as tools to detect stress-adapted and nonadapted plants. International Journal of Plant Science 162: 607-616.

ANGELOPOULOU MV et al. 2009. Fluctuating molar asymmetry in relation to environmental radioactivity. Archives of Oral Biology 54: 666-670.

AUERBACH BM \& RUFF CB. 2006. Limb bone bilateral asymmetry: Variability and commonality among modern humans. Journal of Human Evolution 50: 203-218.

AUFFRAY JC et al. 1999. Shape asymmetry and developmental stability. In: MARK JCM et al. (Ed.). On growth and form: spatio-temporal pattern formation in biology. Nova Jersey: John Wiley and Sons Ltd. p.309-324.

BARONE R. 1999. Anatomie Comparée des mamifères domestiques. Tome 1. Ostéologie. Paris: Vigot. 761p.

BARTOSIEWICZ L et al. 1993. Metapodial asymmetry in draft cattle. International Journal of Osteoarchaeology 3: 69-75.

BERNS CM. 2013. The Evolution of Sexual Dimorphism: Understanding Mechanisms of Sexual Shape Differences. In: MORIYAMA H. (Ed.). Sexual Dimorphism. Londres: IntechOpen. p.1-15.

BETEG F et al. 2007. Lameness, Hoof Care and Functional Trimming in Cows - an Actual Review. Bulletin of University of Agricultural Sciences and Veterinary Medicine Cluj-Napoca - Veterinary Medicine 64: 359-364.

BLACKBURN A. 2011. Bilateral asymmetry of the humerus during growth and development. American Journal of Physical Anthropology 145: 639-646.

BOOKSTEIN FL. 1991. Morphometric Tools for Landmark Data: Geometry and Biology. Cambridge: Cambridge University Press.

CARTER AJR et al. 2009. Heritability of Directional Asymmetry in Drosophila melanogaster. International Journal of Evolutionary Biology 1-7.

CERVENY C. 1985. Anatomical Characteristics on the Ossa Sesamoidea Phalangis Proximalis in Cattle (Bos primigenius F. taurus Linné 1758). Acta Veterinaria Brno 54: 3-22.

COSTA M et al. 2015. Constant fluctuating asymmetry but not directional asymmetry along the geographic distribution of Drosophila antonietae (Diptera, Drosophilidae). Revista Brasileira de Entomologia 59: 337-342.

EBLING RC et al. 2019. Prevalence and distribution of feet lesions in dairy cows raised in the freestall. Semina: Ciências Agrárias 40: 239-248.

GINOT S et al. 2018. Bite Force Performance, Fluctuating Asymmetry and Antisymmetry in the Mandible of Inbred and

Outbred Wild-Derived Strains of Mice (Mus musculus domesticus). Evolutionary Biology 45: 287-302.

GRAHAM JH et al. 1993. Antisymmetry, directional asymmetry, and dynamic morphogenesis. Genetica 89: 121-137.

HAMMER Ø et al. 2001. PAST v. 2.17c. Palaeontologia Electronica 4: 1-229.

KLINGENBERG CP. 2011. MorphoJ: An integrated software package for geometric morphometrics. Molecular Ecology Resources 11: 353-357.

KLINGENBERG CP. 2015. Analyzing fluctuating asymmetry with geometric morphometrics: concepts, methods and applications. Symmetry 7: 843-934.

KUBICKA AM et al. 2018. Bilateral asymmetry of the humerus in Neandertals, Australian aborigines and medieval humans. American Journal of Physical Anthropology 167: 46-60.

MAIERL $\mathrm{J}$ et al. 2002. A method of biomechanical testing the suspensory apparatus of the third phalanx in cattle: a technical note. Anatomia, Histologia, Embryologia 31: 321-325.

MANCINI S et al. 2005. Detection of symmetry and anti-symmetry. Vision Research 45: 2145-2160.

MITTEROECKER P \& GUNZ P. 2009. Advances in Geometric morphometrics. Evolutionary Biology 36: 235-247.

MUGGLIA E et al. 2011. Length asymmetry of the bovine digits. The Veterinary Journal 188: 295-300.

OCAL MK et al. 2004. A quantitative study on the digital bones of cattle. Annals of Anatomy 186: 165-168.

ROHLF FJ. 2010. Digitalized Landmarks and Outlines (2.26). New York: State University of New York.

ROHLF FJ. 2015a. The tps series of software. Hystrix 26: 9-12. 
ROHLF FJ. 2015b. TpsSmall v. 1.33. software.

SFORZA C et al. 1998. Foot asymmetry in healthy adults: Elliptic fourier analysis of standardized footprints. Journal of Orthopaedic Research 16: 758-765.

WILSON GH et al. 2009. Skeletal forelimb measurements and hoof spread in relation to asymmetry in the bilateral forelimb. Equine Veterinary Journal 41: 238-241. 